\title{
TERMINOLOGICAL ANALYSIS OF THE BASIC DEFINITIONS OF STUDYING VOCATIONAL TRAINING OF FUTURE JUNIOR SPECIALISTS IN NURSING IN COLLEGES
}

\author{
М. Р. Демянчук \\ Комунальний заклад вищої освіти «Рівненська медична академія» Рівненської обласної ради \\ ТЕРМІНОЛОГІЧНИЙ АНАЛІЗ ОСНОВНИХ \\ ДЕФІНІЦІЙ ДОСЛІДЖЕННЯ ПРОФЕСІЙНОЇ ПІДГОТОВКИ \\ МАЙБУТНІХ МОЛОДШИХ СПЕЦІАЛІСТІВ СЕСТРИНСЬКОЇ СПРАВИ \\ У КОЛЕДЖАХ
}

\begin{abstract}
The article argues that nowadays a well-established conceptual and terminological apparatus, whose origins have deep historical roots, in modern vocational training of future specialists in nursing of different qualification levels, is used. On the basis of theoretical analysis of scientific literary sources and conceptual and terminological synthesis has been established that definition of "nurse" comes from Latin "nutricius", which means caring for those who suffer. On the basis of comparative analysis the comparative-historical way of becoming nurse profession has been reflected.The basis is a five-stage periodization of the formation and development of nursing (by M. Shehedyn). It has been concretized that in the prehistoric period, which lasted from ancient times to the $\mathrm{V}$ century $\mathrm{AD}$, work that reflected some of the functions of modern nurse was regarded as a spontaneous care, not as a profession; the period of the Middle Ages was marked by the functioning of specialized institutions for the care of sick people; during the Classical period the nursing and Sisters of Charity were born; the Neoclassical period was marked by the development of scientific concepts for the organization of the system of training nurses; in the Modern period the degree nursing education was introduced.

In different historical periods, to indicate the functional characteristics of persons who determine the modern professional activity of nurse, the following terms were used: "deaconess", “caregiver”, "Sister of Mercy”, "Daughter of Charity”, "nurse”. The recognition of nursing staff by the World Health Organization in 1983 as independent and equal in the health care system, as well as the official definition of "nursing", which was considered as an activity aimed at addressing individual and public health problems in a changing environmental conditions, became an extremely important event in development of the world nursing.
\end{abstract}

Key words: concept; terminology; vocational training; medical college; students; nursing; nurses; junior specialists in nursing.

Анотація. У статті аргументовано, що в сучасній професійній підготовці майбутніх фахівців сестринської справи різних кваліфікаційних рівнів нині використовується усталений поняттєво-термінологічний апарат, витоки якого мають глибокі історичні корені. На основі теоретичного аналізу наукових літературних джерел та поняттєво-термінологічного синтезу встановлено, що дефініція «медсестра» («nurse») походить від латинського «nutricius», що означає догляд за тими, хто страждає. На основі компаративного аналізу відображено порівняльно-історичний шлях становлення професії медичної сестри. За основу взято п’ятиетапну періодизацію становлення та розвитку медсестринства (за М. Шегедин). Конкретизовано, що в первісному періоді, який тривав з найдавніших часів до V ст. н. е., робота, яка відображала деякі функції сучасної медичної сестри, розглядалася як стихійний догляд, а не як професія; період середньовіччя відзначався функціонуванням спеціалізованих закладів з догляду за хворими; під час класичного періоду відбулося зародження сестринської справи та сестер милосердя; неокласичний період ознаменувався розробкою наукових концепцій організації системи підготовки медичних сестер; у сучасний період запроваджено ступеневу медсестринську освіту.

У різні історичні періоди для позначення функціональних характеристик осіб, які визначають сучасну професійну діяльність медичної сестри, використовувалися такі терміни: «диякониця», «стариця», «сиділка», «сестра милосердя», «дочка милосердя», «медична сестра». Надзвичайно важливою подією в розвитку світового медсестринства було визнання медсестринського персоналу Всесвітньою організацією охорони здоров’я в 1983 р. як самостійного і рівноправного в системі охорони здоров’я, а також офіційне визначення поняття «сестринська справа», яку розглянуто як діяльність, спрямовану на вирішення проблем індивідуального та громадського здоров’я населення в мінливих умовах навколишнього середовища.

Ключові слова: поняття; термінологія; професійна підготовка; медичний коледж; студенти; сестринська справа; медичні сестри; молодші спеціалісти сестринської справи.

(c) M. R. Demianchuk 
Introduction. Nowadays a well-established and updated conceptual and terminological apparatus, whose origins have deep historical roots, in modern vocational training of future specialists in nursing of different qualification levels, is used. That is why we can argue that definitions, which have evolved historically and characterize the activities of nurses as the patient care art, are used in nursing. It is important that in the process of training of junior specialists in nursing in medical colleges students should have abilities to get acquainted with the basic concepts that characterize the deep essence of the future profession.

There was a need in medical care at different historical stages of the development of humanity. To meet this need of sick, every effort was made by persons who had knowledge and skills to provide the necessary medical services. However, the process of treating patients requires not only the intervention of doctors, but also constant professional care during the whole process of providing medical care to full recovery. Therefore, the problem of preparation for such activity of special staff, which, according to S. Hordiichuk, was formed "from unorganized patient care to science-based care" is updated [2]. Despite the dynamic historical transformations that affected the specifics of work of nursing staff, basis terms and concepts did not undergo significant changes in understanding of their nature.

The aim - to examine the essence of the basic concepts and terms, which are used to characterize nursing staff and which should be considered in the vocational training of future junior specialists in nursing in medical colleges.

Methods. To write a scientific article, methods of analysis of literary sources, which outline the origins of nursing as a profession, have been used. It has been established that the most grounded system analysis of formation and development of nursing, and also the periodization of this process is presented in the works of M. Shehedyn [8-10]. The author's studies clearly spell out the periodization of the history of nursing formation, outline the role of nurse in the process of progressive development of the world medical field.

On the basis of deep analysis of reference, encyclopedic and scientific literature and conceptual and terminological synthesis has been established that the definition of "nurse" comes from Latin "nutricius", which means caring for those who suffer [1].

Based on the comparative analysis (from Lat. Comparativus - comparative) comparative-historical way of becoming a nurse profession has been reflected.
It has been generalized that in prehistoric world the work of nurse was considered as a family care function, not a profession. It has been substantiated that formation and development of profession of "nurse" occurred under the influence not only of different cultures and states, but also of transformation processes in society.

It has been generalized that at the present stage of the development of vocational education of future nurses, the concepts of nursing and nursing activity are usually regarded as identical. Therefore, particular attention should be paid to the research of scholars who have thoroughly studied the historiogenesis of nursing.

Results. Clarification of the essence of basic concepts and terms, which are used in modern nursing education, needs a traceability of the historiogenesis of nursing. The basis was the periodization of the formation and development of nursing, which, according to $\mathrm{M}$. Shehedyn, it is appropriate to divide into five stages:

1) Prehistoric period or the period of elemental care, which lasted from ancient times to the V century AD;

2) Middle Ages - the period of functioning specialized care establishments;

3) Classical period - appearing of nursing and Sisters of Charity;

4) Neoclassical period - development of scientific concepts of organization of the system of nurses training;

5) Modern - the period of introducing level nursing education [8].

According to researchers, nursing could have originated earlier than medicine $[4,5,10]$. Scientists cite evidence of archaeological excavations, which show that about 100 thousand years BC due to supervision (care) people with bone fractures, complex wounds obtained by hunting, fighting, or engaging in ritual processes survived.

Usually women were such carriers of knowledge and abilities in providing primary care and follow-up care. After all, the birth of children whose health, life and development depended mostly on their mothers expanded the responsibilities of women through the awareness of the need to perform diverse care and support tasks. Ancient Slavs called women as "Berehynia" (keeper). It is the feminine name among the first healers - in Egypt (Mighty Polidamna), in Czech Republic (Wise Casa), in Colchis (Medea). In the "Iliad" of Homer wise Agameda treated with healing herbs [5]. Thus, in the history of nursing development, a period of elemental (pre-nursing) care is distinguished, which is related to Greek doctor - 
Asclepius (famous as Aesculapius in Rome literature), who lived in the III century BC. In all asclepions, the building sat the temples in which the sick were treated, most of the women looked after the unable.

For about the first five centuries AD, nursing care was limited to performing hygienic measures and creating comfortable conditions for the needy, homeless and sick. In Ancient Rome, anyone could care for patient for a long time. But, as a rule, this activity, "shameful" from the point of view of the patricians, was the fate of female slaves of Greek or Jewish origin [3].

Later, in Ancient Greece, among the women, who did care, midwives, which could determine the pregnancy terms and the beginning of labor, were emerged. They were given the right to accelerate delivery with medicines and sacred songs, and in ancient Rome, they also looked after women and babies. In the absence of writing, the practice of nursing art was passed on through the folklore, surrounded by superstition.

Middle Ages period (V-XII centuries) was characterized with appearing functioning of specialized establishments of caring for patients. In the next centuries, as Christianity became the dominant religion in Europe, the church took care of the infirm and the sick. Deacons and deaconesses (servants - women, usually widows or virgins over 40 years old) performed this duty. At the beginning of XI century communities of women and girls for serving charity and care for the sick began creation in many cities of Western Europe. Christian charity of the Middle Ages in Catholic countries was also manifested in the creation of various secular and spiritual orders, whose main purpose was to care for the sick person.

The first mention of a medical institution in Kyiv Rus dates back to the $\mathrm{X}$ century, when Princess Olga organized a hospital where the care of patients was entrusted to women. Later, in the tracts of Evpraxia (granddaughter of Volodymyr Monomakh), “Alima” and "Mazi", knowledge of medicine, physiology, propedeutics was gathered and systematized, and in addition to describing illnesses and treatments, personal hygiene advices, including women and children, were submitted [5]. Thus, the setreatises may be considered as the first training manuals necessary for the work of a nurse.

Classical period marked by the birth of the training of future specialists in nursing (XIII - XVIII centuries). New terms appeared during that period: Sister of Mercy, Daughter of Charity. Thus, in 1633 in Paris St. Vincent de Paul and St. Louise de Marillac founded a congregation "Daughters of Charity", which originally dealt only care, work in hospitals.
Having recognized the need for theoretical training for the care of the sick, L. de Marillac first organized seminars for the Sisters of Charity, and in 1641 established a special school for their teaching. At the same period, beguinae appeared - women who cared for patients, trained others to provide the necessary medical care, etc. [4].

Appearing of nursing in Ukraine was marked by the opening in 1773 of the Lviv Obstetric College, and in 1784 - of the Kyiv Academy, which played a significant role in training of medical staff because of the organization of hospital medical schools [6].

Neoclassical period (XIX century) was characterized by the active development of scientific concepts for the organization of the system of training of future nurses. Thus, against the backdrop of the traditional model of care of persons, who need outside help, there is a professional activity that is characterized as nursing through an English nurse Florence Nightingale. In the "Notes on Nursing: What it is and What it is not” (1859) F. Nightingale differentiated cognition of two concepts: caring for the sick and caring for the healthy and on such grounds clarified the essence of nursing: actions, directed to creation of optimal conditions for the recovery of the patient. It was F. Nightingale who emphasized the decisive role of nurse in saving human life and justified the need for special professional training of future specialists in nursing.So, first in England (1860) the first Nursing School at the hospital was opened, and then in other countries: in USA (1872), in Canada (1874). Then in 1899 the first professional human organization International Nursing Council, now considered the largest and most respected international professional organization with offices in nearly 130 countries of the world,was created [10].The first school of nurses in Ukraine was formed at a general hospital in Lviv [9]. By that time, nursing staff were called "caregiver", "Sister of Mercy", but not qualified nurses.

Modern period (XX century till nowadays) is a period of introducing level education for nurses that is marked with licensing of nursing activities (1900s). A very important event in the development of world nursing was recognition of nursing staff by the World Health Organization in 1983 as an independent and equal in the health care system, as well as the official definition of the notion of "nursing", which is considered as an activity aimed at solving the problems of individual and public health of the population in the changing environmental conditions [7].

Conclusions and Prospects for Research. Consequently, a comparative analysis of the history of nursing 
formation as professional activity indicates that, in the historical context, the understanding of the role of persons, who served as nurses, was changed. Thus, the conceptual and terminological apparatus, formation of which depended on the views on the relationship between nurse, patient, society and environment, forming a holistic vision of nursing business, the role

\section{List of literature}

1. Горай О. В. Підготовка майбутніх медичних сестер (фельдшерів) до санітарно-гігієнічного виховання і профілактичної роботи зі школярами : автореф. дис. на здобуття наук. ступеня канд. пед. наук / О. В. Горай. Житомир, 2012. - 20 с.

2. Гордійчук С. В. Європейський та український досвід підготовки кадрів для медсестринства / С. В. Гордійчук, Н. П. Леонченко // Наукові записки Тернопільського національного педагогічного університету імені Володимира Гнатюка. Сер. «Педагогіка». - 2011. № 4. - С. 195-200.

3. Лісовий В. М. Основи медсестринства : підручник / В. М. Лісовий, Л. П. Ольховська, В. А. Капустник. К. : ВСВ «Медицина», 2010. - 792 с.

4. Павлов Ю. И. Теория сестринського дела : пособие / Ю. И. Павлов, А. А. Холопов. - Челябинск, 2006. - 104 с.

\section{References}

1. Horai, O.V. (2012). Pidhotovka maibutnikh medychnykh sester (feldsheriv) do sanitarno-hihiienichnoho vykhovannia i profilaktychnoi roboty zi shkoliaramy [Nurses' (medical assistants') training for the sanitary-hygienic education and preventive work with schoolchildren]. Extended abstract of Candidate's thesis. Zhytomyr [in Ukrainian].

2. Hordiichuk, S.V., \& Leonchenko, N.P. (2011). Yevropeiskyi ta ukrainskyi dosvid pidhotovky kadriv dlia medsestrynstva [European and Ukrainian experience in training of nursing staff]. Naukovi zapysky Ternopilskoho natsionalnoho pedahohichnoho universytetu imeni Volodymyra Hnatiuka. Ser.: Pedahohika - Scientific Issues of Ternopil Volodymyr Hnatiuk National Pedagogical University. Series: Pedagogy, 4, 195-200 [in Ukrainian].

3. Lisovyi, V.M., Olkhovska, L.P., \& Kapustnyk, V.A. (2010). Osnovy medsestrynstva [Fundamentals of nursing]. Kyiv: VSV "Medytsyna” [in Ukrainian].

4. Pavlov, Yu.I., \& Kholopov, A.A. (2006). Teoriya sestrinskogo dela [Theory of nursing]. Chelyabinsk [in Russian]. and place in it of nursing staff, whose activities are based on the universal human principles of ethics and morality, expended.

We see the prospects of further scientific research in the development of educational and methodological support for improving the professional training of future junior specialists in nursing in medical colleges.

5. Пасєчко Н. В. Основи сестринської справи : підручник / Н. В. Пасєчко, М. О. Лемке, П. Є. Мазур. - Тернопіль : Укрмедкнига, 2002. - 544 с.

6. Поцюрко Р. Медсестра - унікальна особистість / Роман Поцюрко // Медична сестра. - 2007. - № 6. C. $42-43$.

7. Тимощук Т. Я. Проблеми медсестринства в медичній освіті / Т. Я. Тимощук // Вища освіта в медсестринстві: проблеми і перспективи : матеріали Всеукр. наук.-практ. конф. (Житомир, 10-11 листоп. 2011 р.). - Житомир : Полісся, 2011. - С. 244-246.

8. Шегедин М. Б. Історія медицини та медсестринства / М. Б. Шегедин, Н. О. Мудрик. - Тернопіль : Укрмедкнига, 2003. - 328 с.

9. Шегедин М. Б. Медсестринство в Україні : навч. посіб. / М. Б. Шегедин. - Тернопіль : Укрмедкнига, 2003. - 280 с. 10. Шегедин М. Б. Медсестринство у світі / М. Б. Шегедин. - Львів : Край, 1999. - 402 с.

5. Pasiechko, N.V., Lemke, M.O., \& Mazur, P.Ye. (2002). Osnovy sestrynskoi spravy [Fundamentals of nursing]. Ternopil: Ukrmedknyha [in Ukrainian].

6. Potsiurko, R. (2007). Medsestra - unikalna osobystist [Nurse is a unique personality]. Medychna sestra - Nurse, 6, 42-43 [in Ukrainian].

7. Tymoshchuk, T.Ya. (2011). Problemy medsestrynstva $\mathrm{v}$ medychnii osviti [Problems of nursing in medical education].Vyshcha osvita $v$ medsestrynstvi: problemy $i$ perspektyvy - Higher Education in Nursing: Challenges and Prospects: Proceedings of the Ukrainian Scientific and Practical Conference. (pp. 244-246). Zhytomyr: Polissia [in Ukrainian].

8. Shehedyn, M.B., \& Mudryk, N.O. (2003). Istoriia medytsyny ta medsystrynstva [History of medicine and nursing]. Ternopil: Ukrmedknyha [in Ukrainian].

9. Shehedyn, M.B. (2003). Medsystrynstvo v Ukraini [Nursing in Ukraine]. Ternopil: Ukrmedknyha [in Ukrainian]. 10. Shehedyn, M.B. (1999). Medsystrynstvo u sviti [Nursing in the world]. Lviv: Krai [in Ukrainian]. 